\title{
Erratum
}

Amare Getahun*

\section{Erratum to: The structure of Argobba nominal phrase}

https://doi.org/10.1515/jall-2018-9011

Erratum to: Amare Getahun. "The structure of Argobba nominal phrase", in: JALL: issue 39, volume 2 (2018), DOI https://doi.org/10.1515/jall-2018-0007.

As the original DOI (https://doi.org/10.1515/jall-2018-0007) was a duplicate, a new DOI has now been assigned. The new DOI is https://doi.org/10.1515/jall2018-0011).

*Corresponding author: Amare Getahun, Department of Amharic Language, Literature and Folklore, Addis Ababa University, Addis Ababa, Ethiopia, E-mail: getam62@gmail.com 